\title{
Impact of Food Processing on the Structural and Allergenic Properties of
}

\section{Food Allergens}

E.N. Clare Mills, Ana I. Sancho, Neil Rigby, John A. Jenkins, Alan R. Mackie. Institute of Food Research

Norwich Research Park

Colney Norwich, NR4 7UA

\section{Introduction}

Two of the major unanswered questions in food allergy research are what makes one person, and not another, become allergic and what are the attributes of some foods and food proteins that make them more allergenic than others? Seeking to answer these questions is much more difficult than investigating the allergenic potency of inhalant or contact allergens since the proteins involved in sensitising or elicting allergic reactions may have undergone extensive modification during food processing and be presented within complex structures within food. These physicochemical changes will alter the way in which they are broken down during digestion and may modify the form in which they are taken up across the gut mucosal barrier and presented to the immune system. Certainly the structure of the food matrix can have a great impact on the elicitation of allergic reactions and fat-rich matrices may affect the kinetics of allergen release, potentiating the severity of allergic reactions (Grimshaw et al., 2003). However, because of its complex nature the impact of food processing and the food matrix on allergenicity of proteins has only recently become a subject of research. Such investigations are fraught with difficulties, not least the fact that food processing often renders food proteins insoluble in the simple salt solutions frequently employed in serological or clinical studies. As a consequence our understanding of the impact of food processing on allergenicity is limited to the more soluble and extractable residues in foods and the allergenic potential of insoluble protein complexes is virtually unstudied despite representing the vast bulk of food proteins consumed.

\section{Proteins in fabricated food structures}

Much of our understanding of the effects of food processing on food protein structure and the fabrication of different types of food structure has been gained from studying model food, 
notably the whey proteins from cow's milk. Others include egg proteins and the $11 \mathrm{~S}$ and $7 \mathrm{~S}$ seed storage globulins, widely distributed abundant proteins found in many edible nuts and seeds and the major components in ingredients such as soya isolates. In addition to their role as a macronutrient, proteins play an important role in forming the structure of processed foods such as foams (for example whipped egg white in meringue), gel networks (such as the white in boiled egg or protein gels found in cooked meat products). They can also play an important role in emulsifying oil in sauces such as mayonnaise, where they form an interconnected adsorbed layer coating the oil droplets, and together with other food ingredients such as sugar, form glassy states in low water foods such as biscuits and pasta. The partially denatured and modified conformations they adopt in such processed foods are similar to those found in processed natural food matrices, where fruits, vegetables nuts or seeds maybe wet-processed (e.g. boiled) or dryheated (e.g. roasted or fried). In this case the interactions are more complex because of the ultrastructure of the natural food matrix where, for example, plant seed proteins maybe compartmentalised in protein bodies, may breakdown during cooking to varying extents.

The types of modification that the food proteins may undergo during processing include protein unfolding and aggregation, in addition to chemical modifications (Figure 1). Both of these have the potential to affect stability to digestion, and hence the form in which allergens are presented to the immune system with regards both sensitisation and elicitation. The extent to which proteins are affected by processing conditions is process dependent, since protein denaturation requires the presence of water, proteins becoming more thermostable in low-water systems (Gekko and Timasheff 1981). Combinations to time and temperature, the presence of other ingredients, such as fats and sugars also affect the patterns and kinetics of food proteins denaturation and aggregation. 


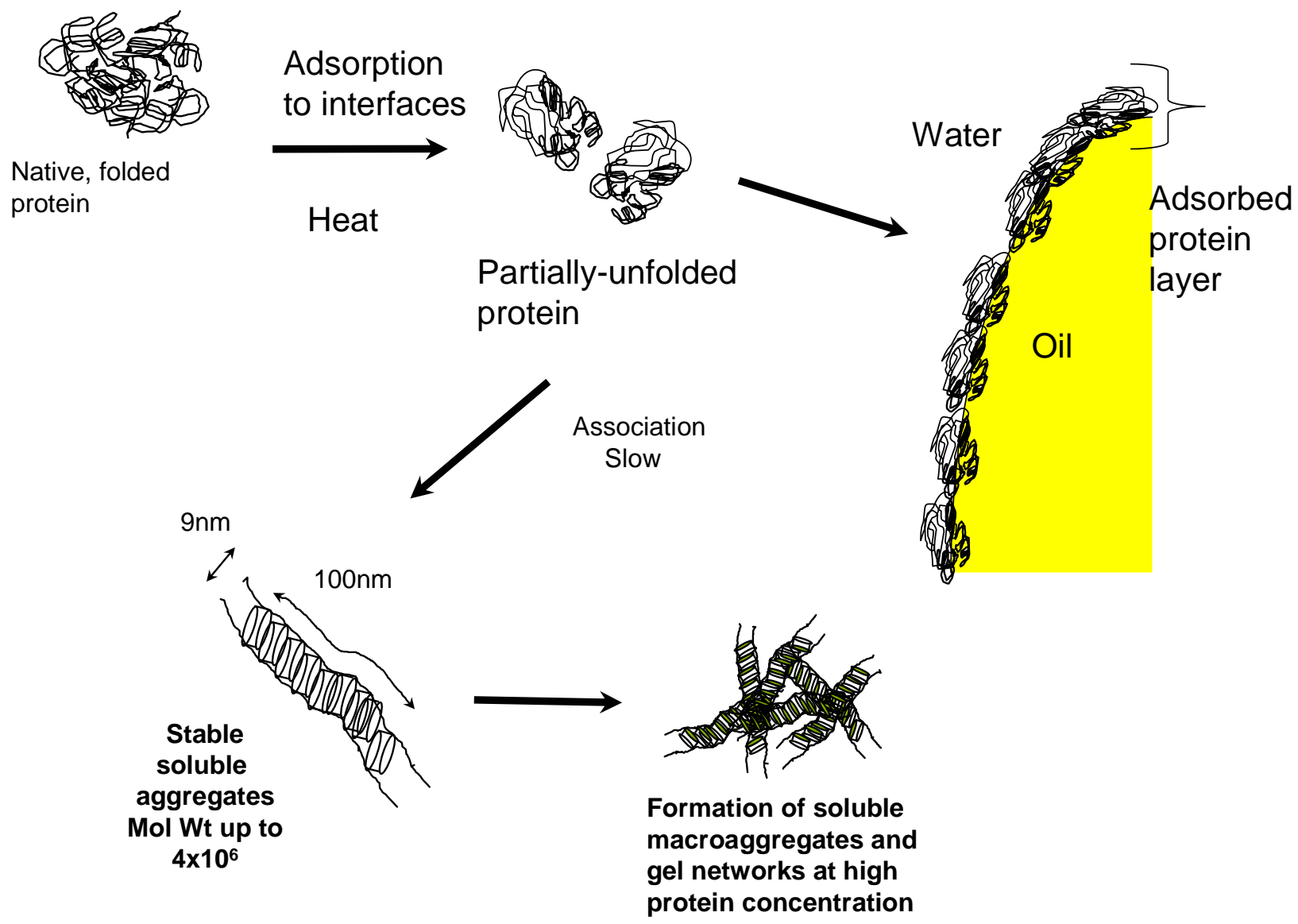

Figure 1: Ways in which proteins can unfold and denature following food processing

One of the most widely studied food proteins is the globular protein $\beta$-lactoglobulin $(\beta-\mathrm{Lg})$, one of the main components of the whey fraction of cow's milk and found in widely used food ingredients such as whey protein isolates and concentrates. $\beta$ - $\mathrm{Lg}$ is a 18,400 dalton retinol binding protein with a $\beta$-barrel structure characteristic of the lipocalin superfamily which is stabilised by two intra-molecular disulphide bonds $\left(\mathrm{Cys}^{106}-\mathrm{Cys}^{119}\right.$, and $\left.\mathrm{Cys}^{66}-\mathrm{Cys}^{160}\right)$ together with a single free cysteine residue (Cys ${ }^{121}$ ) (Brownlow et al., 1997). It is thought that on heating $\beta$-Lg first dissociates into monomers which then partially-unfold before associating into threadlike aggregates around 50nm in diameter (Carrotta et al., 2001;Relkin 1996) which at high protein concentrations will form string-like aggregates which associate to form gel networks (Ikeda and Morris 2002). Unfolding reveals the buried Cys ${ }^{121}$ which is then able to catalyse disulphide interchange to form a non-native monomer in which Cys ${ }^{119}$ is exposed (Croguennec 
et al., 2004) allowing the protein to become linked to other food proteins, such as caseins (Smits and Vanbrouwershaven 1980). This ability to form intermolecular disulphide cross-links affects the mechanical stability of the gels, making them stronger (Alting et al., 2004).

Plant protein ingredients, such as soya isolates, comprise 11S and 7S globulins, in common with other members of the cupin superfamily are thermostable, 7S globulins have their major thermal transition at around $70-75^{\circ} \mathrm{C}$, whilst $11 \mathrm{~S}$ globulins unfold at temperatures above $94^{\circ} \mathrm{C}$, as determined by differential scanning calorimetry. However, even on heating to such temperatures they only appear to partially unfold, undergoing only minor conformational changes suggesting that the $\beta$-barrel motif characteristic of these proteins is a highly stable structure (Mills et al., 2003). Like $\beta$-Lg, these unfolded forms also rapidly form aggregates on heating, which at high protein concentrations $(2.5-10 \%$ by weight) the $7 \mathrm{~S}$ globulin forming string like aggregates akin to whey proteins which also associated to form heat-set gels (Mills et al., 2001).

Protein unfolding and aggregation may also be induced by mixing and shearing that occurs during other food processing, as well as adsorption processes involved in the stabilisation of air:water and oil:water interfaces found in food foams and emulsions. Thus, it appears that adsorbed proteins also undergo only limited unfolding at interfaces (Husband et al., 2001;Burnett et al., 2002) but do form aggregated structures at the interface akin to a semi-2-dimensional gel network (Mackie et al., 2000), which may also be interconnected by disulphide bonds (Dickinson and Matsumura 1991).

All these processes may impact on allergen structure in ways which are often pre-determined by the structure of the protein (Table 1) although the type of process and the addition of other ingredients (e.g. sugars) or $\mathrm{pH}$ may alter the effects. 
Table 1: Impact of food processing on different types of food allergens

\begin{tabular}{|l|l|l|}
\hline \multicolumn{1}{|c|}{$\begin{array}{c}\text { Type of processing } \\
\text { behaviour }\end{array}$} & \multicolumn{1}{c|}{$\begin{array}{c}\text { Effect of thermal } \\
\text { processing }\end{array}$} & \multicolumn{1}{c|}{ Types of food allergen } \\
\hline Processing-labile allergens & $\begin{array}{l}\text { Protein unfolding, } \\
\text { modification by Maillard } \\
\text { adducts in sugar-rich foods, } \\
\text { modification by } \\
\text { polyphenols }\end{array}$ & $\begin{array}{l}\text { Bet v 1 homolgoues from } \\
\text { fuirts such as Mal d 1, Pru } \\
\text { av 1 }\end{array}$ \\
\hline $\begin{array}{l}\text { Partially-denatured } \\
\text { allergens }\end{array}$ & $\begin{array}{l}\text { Partial unfolding of } \\
\text { proteins, aggregation to } \\
\text { form networks as } \\
\text { emulsifiers around lipid or } \\
\text { gelled systems. Maillard } \\
\text { modifications may } \\
\text { potentiate allergenicity. }\end{array}$ & $\begin{array}{l}\text { Cupins allergens, such as } \\
\text { Ara h 1 from peanut. } \\
\text { a-lactalbumin from milk; }\end{array}$ \\
\hline Allergens able to refold & $\begin{array}{l}\text { Proteins unfold to a limited } \\
\text { extent during heating but } \\
\text { can re-fold on cooling. } \\
\text { Maillard modification may } \\
\text { potentiate allergenicity }\end{array}$ & $\begin{array}{l}\text { Prolamin superfamily } \\
\text { members belonging to the } \\
\text { ns LTP, and 2S albumin } \\
\text { sub-families such as Mal d } \\
\text { 3; tropomyosins and } \\
\text { parvalbumins. }\end{array}$ \\
\hline $\begin{array}{l}\text { Mobile rheomorphic } \\
\text { proteins }\end{array}$ & $\begin{array}{l}\text { Proteins do not adopt a rigid } \\
\text { conformation but are very } \\
\text { mobile and consequently do } \\
\text { not denature following } \\
\text { thermal treatment. }\end{array}$ & $\begin{array}{l}\text { Caseins, seed storage } \\
\text { prolamins of wheat (gluten), } \\
\text { ovomucoid }\end{array}$ \\
\hline
\end{tabular}

\section{Effect of processing on allergen structure and properties}

\subsection{Processing-labile proteins}

The best example of allergens which a labile to common food processing technologies are the cross-reactive Bet v 1 superfamily of plant food allergens. It appears that the cross-reactive $\operatorname{IgE}$ responses involved in the pollen-fruit/vegetable cross-reactivity syndrome are primarily directed towards conformation epitopes. For example, two of the cross-reactive IgE epitopes on Bet v 1 homologues of cherry, Pru av 1, appear to be conformational in nature (Neudecker et al., 2001;Gajhede et al., 1996). The Bet v 1 scaffold contains no intramolecular disulphide bonds and appears to be less stable than many other structural types of food allergen, unfolding on heating with a consequential loss of conformational epitopes. Thus, as a general rule both the IgE-reactivity and ability of Bet $\mathrm{v} 1$ homologues to trigger a reaction in sensitized individuals is reduced by food processing, but may depend on the form that processing takes. Whilst cooking 
of fruits such as cherry, which has a high water content, reduces their allergenicity in birchpollen allergic individuals, the application of dry-heat, as in roasting of hazelnuts whilst reducing their allergenicity for many it did not abolish it for all patients (Hansen et al., 2003). This is probably because the application of dry heat does not denature Bet v 1 homologue of hazelnuts, Cor a 1 , as effectively as wet processing would.

It is also emerging that the thermostability of all Bet $\mathrm{v} 1$ homologues is not equivalent, the homologues from celery (Api g 10 and soya (Gly m 4) being more thermostable than Mal d 1 from apple. Thus Ma $1 \mathrm{~d} 1$ unfolds on heating to $90^{\circ} \mathrm{C}$, and does not significantly re-fold on cooling to $20^{\circ} \mathrm{C}$, whilst Api g 1 does not begin to unfold until heated above $80^{\circ} \mathrm{C}$ and regained more of its native structure on cooling (Mills et al in press). Its greater thermostability may contribute to the ability of Api g 1 to retain more of its allergenicity in cooked celery (BallmerWeber et al., 2002) and may underly the observation that Gly $\mathrm{m} 4$ can trigger allergic reactions even in a highly processed soya-based food supplement (Kleine-Tebbe et al., 2002;Mittag et al., 2004).

\subsection{Processing stable allergens}

An allergen family which possess an inherently stable protein scaffold is the prolamin superfamily. These proteins are characterized by a conserved pattern of cysteine residues, with either six or eight such residues forming either three or four intra-chain disulphide bonds which constrain the folded structure of the proteins. With the exception of the prolamin seed storage proteins of cereals, it is these disulphide bonds which play an important role in determining the stability of these proteins to a variety of chemical and physical denaturants, including low $\mathrm{pH}$, chaotropes, high temperature and pressure.

Allergens belonging to the prolamin superfamily which exhibit such stability include the $2 \mathrm{~S}$ albumin allergens such as the Brazil nut allergen Ber e 1 (Alcocer et al., 2002; Moreno et al., 2005b), sesame allergen Ses i 1 (Moreno et al., 2005a), together with the non specific lipid transfer protein (ns LTP) allergens from apple Mal d 3 and grape, Vit v 1 (Vassilopulou et al In press). As they showing some limited unfolding at $90^{\circ} \mathrm{C}$, the ns LTPs may be intrinsically slightly less stable than the $2 \mathrm{~S}$ albumins, probably as a consequence of the lipid binding tunnel, 
although the protein does completely refold on cooling (Moreno et al., 2005b;Sancho et al., 2005). Ligand binding certainly increases the thermostability of ns LTPs increases (Douliez et al., 2001). Severely heat-treatments, such as $100^{\circ} \mathrm{C}$ for $2 \mathrm{~h}$, has been found to significantly reduce the IgE reactivity of the nsLTP allergen from apple, Mal d 3, possibly as a result of one of the disulphides being oxidized (Sancho et al., 2005).

The thermostability of the $2 \mathrm{~S}$ albumin and ns LTP allergens explains the observation that these proteins retain their allergenic properties in processed foods. Thus, even severe thermal processing such as sterilisation at $121^{\circ} \mathrm{C}$ for 30 min does not remove the allergenicity of peach juice (Brenna et al., 2000) nor is it destroyed following boiling or baking $\left(180^{\circ} \mathrm{C}\right)$ of apple peel (Asero et al., 2003). Similarly the allergenicity of maize was retained even after cooking polenta at $100^{\circ} \mathrm{C}$ (Pastorello et al., 2000). Furthermore the IgE reactivity of ns LTPs can even survive fermentation during production of wine (Pastorello et al., 2003) or beer (Asero et al., 2001), despite the fact that the ns LTP in beer is essentially an unfolded highly modified protein (Jegou et al., 2001). These observations may also reflect the fact that many individuals reacting to ns LTPs suffer severe fruit allergy which may influence the way in which their IgE is able to recognize both folded and extensively denatured forms of the protein.

In contrast, in cow's milk allergic individuals, thermal treatments that would cause $\beta-\mathrm{Lg}$ (variants A or B) to denature reduced IgE binding although some trace of $\operatorname{IgE}$ binding remained (Ehn et al., 2005). This may reflect the fact that, depending on the severity of the thermal treatment a proportion of the protein molecules may remain in the native state, which may be sufficient for IgE-reactivity to be retained.

In addition to proteins which possess well-defined three-dimensional structures, there are regions of some proteins which instead comprise ill-defined, disordered, mobile structures (Dunker et al., 2001). Such structures are dynamic and comprise an ensemble of interchanging conformations which does not show the same co-operative transition on heating from a folded to an unfolded or partially folded structure as is observed in more ordered proteins. Two notable examples of food allergens that fall into this category of proteins are caseins from milk and the prolamin seed storage proteins from cereals which form, for example, wheat gluten. There are four structurally 
distinct components found in the casein fraction of cow's milk, $\alpha_{\mathrm{s} 1}-\alpha_{\mathrm{s} 2}-\beta$ - and $\kappa$-casein which assemble into casein micelles in milk. The absence of a co-operative transition as determined by DSC and their lack of secondary structure has led to them being termed rheomorphic, rheo meaning to flow, and morphe meaning shape, a property shared by seed storage prolamins (Paulsson and Dejmek 1990;Holt and Sawyer 1993). As a consequence of their dynamic nature, these proteins possess many linear, and hence potentially thermo-stable, IgE epitopes and is probably the reason why the IgE binding capacity of caseins and wheat prolamins is largely unaltered by thermal processing (Simonato et al., 2001;Kohno et al., 1994)..

Stability to processing is also a function of the process itself. Thus many seed storage globulins will denature to some extent and form aggregated networks following heating in a highly hydrated state (Mills et al., 2002) and those from many legumes such soybean and lentils, are consumed in a boiled form. However, peanuts and many tree nuts are often consumed after being thermally processed at low water levels, in a roasted or fried form. Studies on the seed storage globulin allergen from peanuts are difficult to undertake as much of the peanut protein becomes insoluble. Nevertheless they indicate that the protein only becomes unfolded on roasting peanuts to $140^{\circ} \mathrm{C}$ for $15 \mathrm{~min}$, (Koppelman et al., 1999). IgE binding to wet or dry-heat denatured protein was essentially unchanged leading to the suggestion that either Ara $\mathrm{h} 1$ does not contain any conformational epitopes, or that they are restricted to the thermostable regions of the structure.

\section{Processing induced chemical modification of allergens}

One of the main chemical modifications that occurs in foods during processing is the reaction between free amino groups on proteins and the aldehyde or ketone groups of sugars kown as Maillard's reaction. Such non-enzymatic glycations reactions can subsequently undergo a range of further rearrangements giving rise to a range of structurally diverse compounds known as Amadori products or advanced glycation end products $\left(A G E_{S}\right)$. The formation of these adducts is affected by types of non-reducing sugars $\mathrm{pH}$, water activity, temperature and is important as the volatile compounds contribute to the aromas and flavours associated with many cooked foods. The rearrangement products can result in the cross-linking of food proteins, and in studies on the IgE-reactivity of bread in a panel of wheat allergic individuals suggested that some of the IgEreactive protein was extensively cross-linked by Maillard adducts (Simonato et al., 2001). 
Maillard modification may affect the allergenicity of food proteins. Thus Maillard modifications can cross-link the peanut allergens Ara $h 1$ and Ara $h 2$ to form high molecular weight aggregates which bind IgE more effectively than unmodified allergens, and are also more resistant to gastric digestion (Maleki et al., 2000), IgE binding to modified proteins being partially inhibited by antibodies to AGE adducts (Chung et al., 2003). IgE from human peanut allergic sera binds peanut allergens Ara h 1, 2 and 3 more strongly from roasted compared with boiled or fried peanuts (Beyer et al., 2001) (indicating that certain types of thermal processing can introduce additional IgE binding sites. However, these observations may be complicated by the fact that peanut allergens leach out of peanuts during boiling, lowering the residual allergen content in the boiled nuts (Mondoulet et al., 2005). Maillard modification has also been found to increase the IgE-binding capacity of the allergenic shellfish tropomyosin (Nakamura et al., 2005). Individuals may have become sensitised to glycated tropomyosin itself, through consumption of the dried fish products frequently used, especially in oriental cuisine.

However, glycation of fruit allergens does not appear to increase their allergenicity in the same way as the peanut or shell-fish allergens. Thus, glycation of Pru av 1, the allergenic Bet v 1 homologue of cherry, with sugars, such as fructose and ribose, significantly reduced the proteins IgE reactivity, whilst modification with carbonyl compounds formed during carbohydrate breakdown, such as glyoxal and glycoaldehyde, almost completely abolished IgE binding (Gruber et al., 2004). Maillard modification of the nsLTP allergen from apple, Mal d 3, protected the IgE-binding capacity of the protein following harsh thermal treatment (Sancho et al., 2005).

Other types of processing-induced modification which may affect allergenicity include interactions with oxidsed lipids ((Doke et al., 1989) and enzymatic modification with polyphenols catalysed by the polyphenol oxidase. Modification with epichatechin and caffeic acid was found to reduce the IgE-binding capacity of Pru av 1. However the extent to which it was reduced was highly dependent on the polyphenol involved, quercetin and quercetinglycoside, rutin, having a lesser effect (Gruber et al., 2004). Such enzymatic modifications may be responsible for the highly labile nature of many fruit Bet $\mathrm{v} 1$ type allergens. 


\section{Understanding the impact of processing on allergenic potential and managing risk}

Understanding the impact of food processing and food structure on allergenic potential is central to managing allergen risks in the food chain. However, our current knowledge of the impact of food processing on allergen structure indicates that there are no clear rules regarding how different allergens respond to food processing. Thus for some, such as the Bet $\mathrm{v} 1$ family of allergens found in fruits and vegetables, their allergenicity is destroyed by cooking, but for many others it is unaltered or may even be increased. What is emerging is that the impact is related to the type of sensitivity (is it related to an inhalant allergy or does it involve oral sensitisation by ingestion of food), the structural attributes and inherent stability of the allergen scaffold, the type of processing the allergen is subjected to and the food structure in which the allergen becomes embedded.

Investigations into the impact of processing on allergen structure and allergenic potential are still in their infancy, but two areas that remain neglected are the impact that food processing procedures have on sensitisation potential that modify allergenic potential and the way in which it may alter thresholds for elicitation of allergic reactions in sensitised individuals. A knowledge of how processing or food structure may alter threshold doses of allergens able to elicit an allergic reaction is highly relevant for managing allergens in a factory environment, particularly in relation to cross-contact allergens. In such instances allergens may find their way into foods otherwise free from them, through use of parallel or common processing lines for manufacture of allergen containing or allergen free foods. It may be that certain types of food structure, for example fat-continuous versus aqueous continuous matrices, may raise or lower the threshold doses for important allergens such as those from peanut. Such information is necessary to inform hazard control procedures as it may affect the extent to which it is necessary to clean-down common processing lines or the rigour with which ingredients are segregated within a factory environment. It is also acknowledged that food processing can affect the responsiveness of the immunoassay methods used to monitor allergens in foods and equipment clean-down (Poms et al., 2004). A better understanding of how processing affects allergen structure, and hence allergen screening assays, would help support interpretation of immunoassay results especially when used to monitor highly processed ingredients. 
Another aspect of allergen management in foods is the allergenic risk assessment process which forms part of the regulatory framework of Novel Foods and Processes. Our lack of understanding of the impact of conventional food processing procedures also makes the assessment of novel processes, such as high pressure, or novel thermal processing procedures, less certain than would otherwise be the case. The complexity of food processing makes managing allergens in foods difficult but demonstrates the importance of understanding its impact at the molecular level if risk assessors are to move towards knowledge-based ways of managing allergen risks.

\section{Acknowledgements}

This work was supported by the competitive strategic grant to IFR from BBSRC. 


\section{References}

1. Alcocer M.J.C., Murtagh G.J., Bailey K., Dumoulin M., Meseguer A.S., Parker M.J. and Archer D.B. (2002) The disulphide mapping, folding and characterisation of recombinant Ber e 1, an allergenic protein, and SFA8, two sulphur-rich $2 \mathrm{~S}$ plant albumins. Journal of Molecular Biology 324, 165-175.

2. Alting A.C., Weijers M., De Hoog E.H.A., van de Pijpekamp A.M., Stuart M.A.C., Hamer R.J., De Kruif C.G. and Visschers R.W. (2004) Acid-induced cold gelation of globular proteins: Effects of protein aggregate characteristics and disulfide bonding on rheological properties. Journal of Agricultural and Food Chemistry 52, 623-631.

3. Asero R., Mistrello G., Roncarolo D., Amato S. and Falagiani P. (2003) Analysis of the heat stability of lipid transfer protein from apple. Journal of Allergy and Clinical Immunology 112, 1009-1011.

4. Asero R., Mistrello G., Roncarolo D., Amato S. and van Ree R. (2001) A case of allergy to beer showing cross-reactivity between lipid transfer proteins. Ann.Allergy Asthma Immunol. 87, 65-67.

5. Ballmer-Weber B.K., Hoffmann A., Wuthrich B., Luttkopf D., Pompei C., Wangorsch A., Kastner M. and Vieths S. (2002) Influence of food processing on the allergenicity of celery: DBPCFC with celery spice and cooked celery in patients with celery allergy. Allergy 57, 228-235.

6. Beyer K., Morrow E., Li X.M., Bardina L., Bannon G.A., Burks A.W. and Sampson H.A. (2001) Effects of cooking methods on peanut allergenicity. J.Allergy Clin.Immunol. 107, 1077-1081.

7. Brenna O., Pompei C., Ortolani C., Pravettoni V., Farioli L. and Pastorello E.A. (2000) Technological processes to decrease the allergenicity of peach juice and nectar. J.Agric.Food Chem. 48, 493-497.

8. Brownlow S., Cabral J.H.M., Cooper R., Flower D.R., Yewdall S.J., Polikarpov I., North A.C.T. and Sawyer L. (1997) Bovine beta-lactoglobulin at 1.8 angstrom resolution - Still an enigmatic lipocalin. Structure 5, 481-495.

9. Burnett G.R., Rigby N.M., Mills E.N.C., Belton P.S., Fido R.J., Tatham A.S. and Shewry P.R. (2002) Characterization of the emulsification properties of $2 \mathrm{~S}$ albumins from sunflower seed. Journal of Colloid and Interface Science 247, 177-185.

10. Carrotta R., Bauer R., Waninge R. and Rischel C. (2001) Conformational characterization of oligomeric intermediates and aggregates in beta-lactoglobulin heat aggregation. Protein Science 10, 1312-1318. 
11. Chung S.Y., Butts C.L., Maleki S.J. and Champagne E.T. (2003) Linking peanut allergenicity to the processes of maturation, curing, and roasting. Journal of Agricultural and Food Chemistry 51, 4273-4277.

12. Croguennec T., Molle D., Mehra R. and Bouhallab S. (2004) Spectroscopic characterization of heat-induced nonnative beta-lactoglobulin monomers. Protein Science 13, 1340-1346.

13. Dickinson E. and Matsumura Y. (1991) Time-Dependent Polymerization of BetaLactoglobulin Through Disulfide Bonds at the Oil-Water Interface in Emulsions. International Journal of Biological Macromolecules 13, 26-30.

14. Doke S., Nakamura R. and Torii S. (1989) Allergenicity of Food Proteins Interacted with Oxidized Lipids in Soybean-Sensitive Individuals. Agricultural and Biological Chemistry 53, 1231-1235.

15. Douliez J.P., Jegou S., Pato C., Molle D., Tran V. and Marion D. (2001) Binding of two mono-acylated lipid monomers by the barley lipid transfer protein, LTP1, as viewed by fluorescence, isothermal titration calorimetry and molecular modelling. European Journal of Biochemistry 268, 384-388.

16. Dunker A.K., Lawson J.D., Brown C.J., Williams R.M., Romero P., Oh J.S., Oldfield C.J., Campen A.M., Ratliff C.R., Hipps K.W., Ausio J., Nissen M.S., Reeves R., Kang C.H., Kissinger C.R., Bailey R.W., Griswold M.D., Chiu M., Garner E.C. and Obradovic Z. (2001) Intrinsically disordered protein. Journal of Molecular Graphics \& Modelling 19, $26-59$.

17. Ehn B.M., Allmere T., Telemo E., Bengtsson U. and Ekstrand B. (2005) Modification of IgE binding to beta-lactoglobulin by fermentation and proteolysis of cow's milk. Journal of Agricultural and Food Chemistry 53, 3743-3748.

18. Gajhede M., Osmark P., Poulsen F.M., Ipsen H., Larsen J.N., vanNeerven R.J.J., Schou C., Lowenstein H. and Spangfort M.D. (1996) X-ray and NMR structure of Bet v 1, the origin of birch pollen allergy. Nature Structural Biology 3, 1040-1045.

19. Gekko K. and Timasheff S.N. (1981) Mechanism of Protein Stabilization by Glycerol Preferential Hydration in Glycerol-Water Mixtures. Biochemistry 20, 4667-4676.

20. Grimshaw K.E.C., King R.M., Nordlee J.A., Hefle S.L., Warner J.O. and Hourihane J.O.B. (2003) Presentation of allergen in different food preparations affects the nature of the allergic reaction - a case series. Clinical and Experimental Allergy 33, 1581-1585.

21. Gruber P., Vieths S., Wangorsch A., Nerkamp J. and Hofmann T. (2004) Maillard reaction and enzymatic browning affect the allergenicity of Pru av 1, the major allergen from cherry (Prunus avium). Journal of Agricultural and Food Chemistry 52, 4002-4007.

22. Hansen K.S., Ballmer-Weber B.K., Luttkopf D., Skov P.S., Wuthrich B., Bindslev-Jensen C., Vieths S. and Poulsen L.K. (2003) Roasted hazelnuts - allergenic activity evaluated by double-blind, placebo-controlled food challenge. Allergy 58, 132-138. 
23. Holt C. and Sawyer L. (1993) Caseins As Rheomorphic Proteins - Interpretation of Primary and Secondary Structures of the Alpha-S1-Caseins, Beta-Caseins and Kappa-Caseins. Journal of the Chemical Society-Faraday Transactions 89, 2683-2692.

24. Husband F.A., Garrood M.J., Mackie A.R., Burnett G.R. and Wilde P.J. (2001) Adsorbed protein secondary and tertiary structures by circular dichroism and infrared spectroscopy with refractive index matched emulsions. Journal of Agricultural and Food Chemistry 49, 859-866.

25. Ikeda S. and Morris V.J. (2002) Fine-stranded and particulate aggregates of heat-denatured whey proteins visualized by atomic force microscopy. Biomacromolecules 3, 382-389.

26. Jegou S., Douliez J.P., Molle D., Boivin P. and Marion D. (2001) Evidence of the glycation and denaturation of LTP1 during the malting and brewing process. Journal of Agricultural and Food Chemistry 49, 4942-4949.

27. Kleine-Tebbe J., Wangorsch A., Vogel L., Crowell D.N., Haustein U.F. and Vieths S. (2002) Severe oral allergy syndrome and anaphylactic reactions caused by a Bet v 1-related PR-10 protein in soybean, SAM22. Journal of Allergy and Clinical Immunology 110, 797-804.

28. Kohno Y., Honma K., Saito K., Shimojo N., Tsunoo H., Kaminogawa S. and Niimi H. (1994) Preferential Recognition of Primary-Protein Structures of Alpha-Casein by Igg and Ige Antibodies of Patients with Milk Allergy. Annals of Allergy 73, 419-422.

29. Koppelman S.J., Bruijnzeel-Koomen C.A., Hessing M. and de Jongh H.H. (1999) Heatinduced conformational changes of Ara $\mathrm{h} \mathrm{1,}$, a major peanut allergen, do not affect its allergenic properties. J.Biol.Chem. 274, 4770-4777.

30. Mackie A.R., Gunning A.P., Wilde P.J. and Morris V.J. (2000) Orogenic displacement of protein from the oil/water interface. Langmuir 16, 2242-2247.

31. Maleki S.J., Chung S.Y., Champagne E.T. and Raufman J.P. (2000) The effects of roasting on the allergenic properties of peanut proteins. J.Allergy Clin.Immunol. 106, 763-768.

32. Mills E.N., Jenkins J., Marigheto N., Belton P.S., Gunning A.P. and Morris V.J. (2002) Allergens of the cupin superfamily. Biochem.Soc.Trans. 30, 925-929.

33. Mills E.N.C., Huang L., Noel T.R., Gunning A.P. and Morris V.J. (2001) Formation of thermally induced aggregates of the soya globulin beta-conglycinin. Biochimica et Biophysica Acta-Protein Structure and Molecular Enzymology 1547, 339-350.

34. Mills E.N.C., Marigheto N.A., Wellner N., Fairhurst S.A., Jenkins J.A., Mann R. and Belton P.S. (2003) Thermally induced structural changes in glycinin, the $11 \mathrm{~S}$ globulin of soya bean (Glycine max) - an in situ spectroscopic study. Biochimica et Biophysica Acta-Proteins and Proteomics 1648, 105-114.

35. Mittag D., Vieths S., Vogel L., Becker W.M., Rihs H.P., Helbling A., Wuthrich B. and Ballmer-Weber B.K. (2004) Soybean allergy in patients allergic to birch pollen: clinical 
investigation and molecular characterization of allergens. J.Allergy Clin.Immunol. 113, 148154.

36. Mondoulet L., Paty E., Drumare M.F., Ah-Leung S., Scheinmann P., Willemot R.M., Wal J.M. and Bernard H. (2005) Influence of thermal processing on the allergenicity of peanut proteins. Journal of Agricultural and Food Chemistry 53, 4547-4553.

37. Moreno F.J., Maldonado B.M., Wellner N. and Mills E.N.C. (2005a) Thermostability and in vitro digestibility of a purified major allergen $2 \mathrm{~S}$ albumin (Ses i 1) from white sesame seeds (Sesamum indicum L.). Biochimica et Biophysica Acta-Proteins and Proteomics 1752, 142153.

38. Moreno F.J., Mellon F.A., Wickham M.S.J., Bottrill A.R. and Mills E.N.C. (2005b) Stability of the major allergen Brazil nut $2 \mathrm{~S}$ albumin (Ber e 1) to physiologically relevant in vitro gastrointestinal digestion. Febs Journal 272, 341-352.

39. Nakamura A., Watanabe K., Ojima T., Ahn D.H. and Saeki H. (2005) Effect of Maillard reaction on allergenicity of scallop tropomyosin. Journal of Agricultural and Food Chemistry 53, 7559-7564.

40. Neudecker P., Schweimer K., Nerkamp J., Scheurer S., Vieths S., Sticht H. and Rosch P. (2001) Allergic cross-reactivity made visible: solution structure of the major cherry allergen Pru av 1. J.Biol.Chem. 276, 22756-22763.

41. Pastorello E.A., Farioli L., Pravettoni V., Ispano M., Scibola E., Trambaioli C., Giuffrida M.G., Ansaloni R., Godovac-Zimmermann J., Conti A., Fortunato D. and Ortolani C. (2000) The maize major allergen, which is responsible for food-induced allergic reactions, is a lipid transfer protein. J.Allergy Clin.Immunol. 106, 744-751.

42. Pastorello E.A., Farioli L., Pravettoni V., Ortolani C., Fortunato D., Giuffrida M.G., Garoffo L.P., Calamari A.M., Brenna O. and Conti A. (2003) Identification of grape and wine allergens as an endochitinase 4, a lipid-transfer protein, and a thaumatin. Journal of Allergy and Clinical Immunology 111, 350-359.

43. Paulsson M. and Dejmek P. (1990) Thermal-Denaturation of Whey Proteins in Mixtures with Caseins Studied by Differential Scanning Calorimetry. Journal of Dairy Science 73, 590-600.

44. Poms R.E., Klein C.L. and Anklam E. (2004) Methods for allergen analysis in food: a review. Food Addit.Contam 21, 1-31.

45. Relkin P. (1996) Thermal unfolding of beta-lactoglobulin, alpha-lactalbumin, and bovine serum albumin. A thermodynamic approach. Critical Reviews in Food Science and Nutrition 36, 565-601.

46. Sancho A.I., Rigby N.M., Zuidmeer L., Asero R., Mistrello G., Amato S., GonzalezMancebo E., Fernandez-Rivas M., Ree R. and Mills E.N.C. (2005) The effect of thermal processing on the IgE reactivity of the non-specific lipid transfer protein from apple, Mal d 3. Allergy 60, 1262-1268. 
47. Simonato B., Pasini G., Giannattasio M., Peruffo A.D., De Lazzari F. and Curioni A. (2001) Food allergy to wheat products: the effect of bread baking and in vitro digestion on wheat allergenic proteins. A study with bread dough, crumb, and crust. J.Agric.Food Chem. 49, 5668-5673.

48. Smits P. and Vanbrouwershaven J.H. (1980) Heat-Induced Association of BetaLactoglobulin and Casein Micelles. Journal of Dairy Research 47, 313-325. 